\title{
Mapping of the Use of Waste as Raw Materials for Biogas Production
}

\author{
Rafaela Lora Grando ${ }^{1 *}$, Fabiana Valeria da Fonseca ${ }^{2}$, Adelaide Maria de Souza Antunes ${ }^{2,3}$ \\ ${ }^{1}$ Graduate Program in Chemical and Biochemical Processes, School of Chemistry, Universidade Federal do Rio de Janeiro, Rio de \\ Janeiro, Brazil \\ ${ }^{2}$ Universidade Federal do Rio de Janeiro, Rio de Janeiro, Brazil \\ ${ }^{3}$ Instituto Nacional de Propriedade Industrial (INPI), Rio de Janeiro, Brazil \\ Email: *rafaela.lora.grando@gmail.com
}

How to cite this paper: Grando, R.L., Fonseca, F.V. and Antunes, A.M.S. (2017) Mapping of the Use of Waste as Raw Materials for Biogas Production. Journal of Environmental Protection, 8, 120-130. https://doi.org/10.4236/jep.2017.82010

Received: July 22, 2016

Accepted: February 7, 2017

Published: February 10, 2017

Copyright $\odot 2017$ by authors and Scientific Research Publishing Inc. This work is licensed under the Creative Commons Attribution International License (CC BY 4.0).

http://creativecommons.org/licenses/by/4.0/ (c) (i) Open Access

\begin{abstract}
Anthropic methane emissions can largely be prevented or minimized using technologies that are already available. One such technology is anaerobic digestion (AD), which is used commercially around the world, especially in Europe and the United States, where some challenging targets have been set to diversify the energy mix with more renewable energy. This foresight study was designed to identify which technological solutions out of the many options available for biogas production are attracting most interest, for which purpose patent documents and scientific publications were analyzed. The aim is to identify which raw materials are most attractive for $\mathrm{AD}$ and biogas production. It was found that the raw materials that have attracted most research and patenting activity are sludge, sewage, and wastewater, livestock waste, and agriculture waste, which together account for $62 \%$ of all the patents filed and $74 \%$ of all the scientific publications. The countries most engaged in producing biogas from AD plants are China, Germany, and the United States. We also identified a rising trend in the use of biogas around the world, and a steady increase in the number of patents filed on the subject, especially in Japan and South Korea. This growth is driven, amongst other things, by strategic governmental actions, global environmental pacts, and the realization on the part of industry that anaerobic digestion can be used as an efficient method for treating waste and effluents.
\end{abstract}

\section{Keywords}

Anaerobic Digestion, Biogas Production, Investigative Overview, Raw Material

\section{Introduction}

The development of sustainable technologies that combine the use of waste ma- 
terials or byproducts with energy generation is gaining ground, especially since the oil crisis in the 1970s, when heightened interest in energy recovery and reducing environmental pollution was first awakened. Anaerobic digestion (AD) is a useful energy production technique. It is used to break down waste of primarily organic content through the action of microbes, producing biogas and highquality fertilizer. Other benefits of using $\mathrm{AD}$ include: flexibility in the choice of feedstock for the process; reduced dependency on fossil fuels; lower greenhouse gas (GHG) emissions; contribution to rural socioeconomic development; and a feasible means to help countries attain the gas emission and waste treatment targets established in international agreements. The average chemical composition of the biogas produced by anaerobic digestion is: $50 \%-85 \% \mathrm{CH}_{4}$ (methane), $20 \%-35 \% \mathrm{CO}_{2}$ (carbon dioxide), and varying quantities of $\mathrm{H}_{2}, \mathrm{~N}_{2}$, and water vapor [1]. When it is purified and the methane fraction is separated off, the energy content of this gas is similar to natural gas.

What really sets $\mathrm{AD}$ apart is the fact that it can be used to treat industrial waste, agricultural waste, animal waste, sewage, sludge, and wastewater, since the main prerequisite is that the feedstock used must be primarily organic [2]. A series of prerequisites must also be fulfilled if the efficiency of biogas production by anaerobic digestion is to be assured. The most important thing is to create an ecosystem that is favorable for the development and metabolic activity of the microorganisms involved in the process. It is often hard to find an ideal raw material, and a combination of substrates can be used to ensure the feedstock fits the operational parameters. There are a great many factors that affect $\mathrm{AD}$ processes, like the organic load, $\mathrm{pH}$, equipment, hydraulic retention time, and temperature [3].

In the early 1990s, co-digestion started to emerge as a new technique for overcoming the limitations of the $\mathrm{AD}$ process, whereby different raw materials are processed together [4]. Working with a combination of feedstocks, co-digestion has the benefits of: diluting the substrate and adjusting the $\mathrm{C}: \mathrm{N}$ ratio, for instance; fostering a balance of nutrients; contributing to the microbial community; reducing production costs; and increasing the load of biodegradable organic matter, thereby increasing the associated yield of biogas [5].

For many years, anaerobic digestion has been used successfully for treating domestic, industrial, farm, food, and municipal solid waste, as well as other types of waste. It is employed in different parts of the globe and is quite widely used, especially in rural parts, where there is a ready supply of feedstocks with a high organic load [6]. The potential for biogas production can be divided into: 75\% from agricultural crops, byproducts and manure; 17\% from municipal and industrial solid waste; and $8 \%$ from sewage, sludge, and wastewater [7].

Many studies have indicated that anaerobic digestion is an environmentally friendly and efficient way of generating energy and producing fertilizer. Indeed, rural communities in particular have much to gain socially and economically from producing and using biogas [8]. In view of the great versatility of anaerobic digestion and the almost infinite variety of potential feedstocks it can use, find- 
ing out more about which waste materials have the greatest potential for biogas production in $\mathrm{AD}$ units is clearly worthwhile.

Technology foresight is one of the most widely used methods for investigating the future use of given technologies, mapping out and giving an overview of a production chain or process. In this research, a foresight study of AD was conducted by investigating patenting activity and scientific publications on the subject [9] [10].

\section{Foresight Methodology}

Patent documents were retrieved from the Derwent Innovations Index and imported into VantagePoint ${ }^{\oplus}$, version 5.0 (2007), a commercial software package for text mining and data organization. The search strategy was based on specific keywords and certain Derwent Manual Codes. These codes are provided by the database and operate in much the same way as the International Patent Classification (IPC), in that the patent documents are read and then assigned to codes according to the scope of protection of the inventions they describe. The search retrieved documents indexed in the database between 2000 and May 2016, and the following Derwent Manual Codes were used: D05-C14 (Methane) and H06-A04 (Biofuel gases e.g. methane production by digestion or fermentation of e.g. waste organic materials). The patents' titles and abstracts were searched using the keyword "biogas" and its synonyms, like "greengas" and "biomethane". Keywords were then used to identify which of the retrieved patents referred to some specific feedstock, and these were then sorted into groups (Table 1).

Table 1. Keywords searched in the patent database.

\begin{tabular}{|c|c|}
\hline Group & Keywords \\
\hline Animal Waste & $\begin{array}{c}\text { animal OR swine OR pig OR excrement OR livestock OR manure OR } \\
\text { chicken OR dairy OR dung OR poultry OR cattle OR slurry OR urine } \\
\text { OR horse OR sheep, duck OR mule OR rabbit OR llama OR bull OR } \\
\text { horse OR elephant OR giraffe OR buffalo }\end{array}$ \\
\hline Wastewater & wastewater OR waste water OR sewage OR sludge \\
\hline Municipal Solid Waste & $\begin{array}{c}\text { garbage OR "solid urban residue" OR OFMSW OR } \\
\text { "household" OR “municipalwaste" OR biowaste OR } \\
\text { "organic fraction of municipal solid waste" }\end{array}$ \\
\hline Food Waste & $\begin{array}{l}\text { "food waste" OR "kitchen waste" OR "vegetable waste" OR } \\
\text { "fruit waste" OR "foodstuffs" }\end{array}$ \\
\hline Agricultural Waste & $\begin{array}{c}\text { maize OR agriculture OR stalks OR straw OR cotton OR beet OR corn } \\
\text { OR rice OR cereal OR agricultural OR silage OR crop OR sorghum }\end{array}$ \\
\hline Lignocellulosic Waste & $\begin{array}{l}\text { wood OR cellulose OR cellulosic OR branches OR leave* OR } \\
\text { lignocellulosic OR firewood OR grass OR yard OR "sugarcane bagasse" }\end{array}$ \\
\hline Industrial Waste & $\begin{array}{l}\text { “paper waste" OR palm oil OR stillage OR brewery OR glycerin OR } \\
\text { “textile industry" OR fishery OR “industrial waste” OR “industrial } \\
\text { residue" OR "fabric residue” OR tannery OR "winery waste” }\end{array}$ \\
\hline Algae & Algae OR microalgae OR “aquatic plants” \\
\hline
\end{tabular}


This search for patent documents yielded 11,625 documents for AD technology and biogas production, but only $21 \%$ of these mentioned the use of a specific kind of waste, reducing the total number of patent documents for analysis to 2493.

Afterwards, in order to identify the research done on each groups of feedstocks identified in the patent documents, a search of scientific publications was conducted. All the publications indexed in the Web of Science between 2000 and June 2016 were retrieved. A different search strategy was used for each group of raw materials identified in the patents, employing the same keywords as used to retrieve the patents (see Table 1) in combination with "biogas" and its synonyms. Next, an analysis was performed to identify what progress has been made in the potential feedstocks for biogas generation.

\title{
3. Results and Discussion
}

Using the strategy described above, 2493 patent documents were retrieved, which were sorted into groups according to the kind of waste material they were for (Figure 1). Some of the patents-especially for novel processes-made mention of more than one waste material and were considered once in each corresponding group. The possibility of more than one waste material being covered by a single patent claim, especially for equipment, devices, reactors, or tanks, suggests that there is a degree of multifunctionality in the equipment used. Likewise, when more than one feedstock was mentioned in the same patent claim, this could indicate the use or possible use of co-digestion.

In anaerobic digestion, the composition of the feedstock can have a direct impact on the final yield of methanol in the biogas. When fat is degraded, the fatty acid content in the fermentation medium rises, which limits and slows down the overall degradation of the feedstock [11].

The search for scientific publications was based on the main types of feedstock found in the patents. The breakdown per year is shown in Figure 2. Although publications indexed between 2000 and 2016 were retrieved, the information in

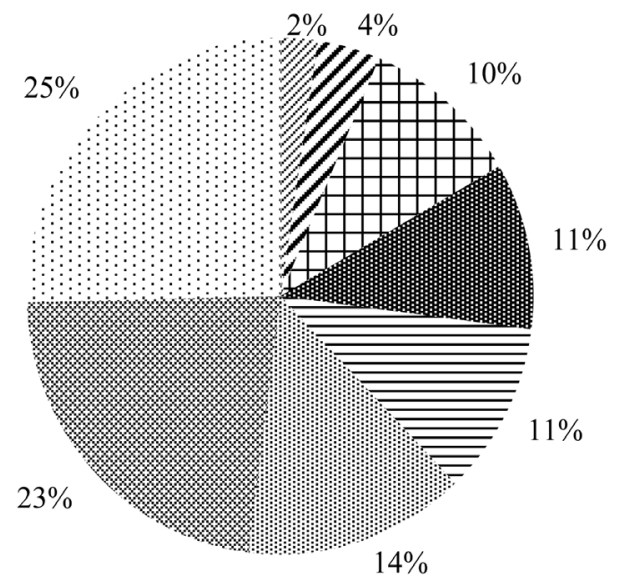

\author{
\% Algae and aquatic plants \\ Industrial waste \\ + Municipal Solid Waste \\ 䀧Food waste \\ = Cellulosic waste \\ : Agricultural waste \\ * Livestock Waste \\ : Sludge, Wastewater and Sewage
}

Figure 1. Breakdown of patent applications by type of feedstock mentioned in the abstracts. 
Figure 2 only covers the period from 2010 to 2016 because it was only as of 2010 that there was a significant volume of publications on the subject. The papers are grouped by type of feedstock and year of publication.

In addition, Figure 3 lists the top five countries where priority patent applications have been filed per type of feedstock. Meanwhile, Figure 4 shows the breakdown of the publications per feedstock by the countries of affiliation of the lead authors (countries of the institutions to which they are affiliated). The Figure 4 only shows the countries with over 100 publications (according to the country of the institution to which the lead authors are affiliated). To facilitate understanding, the discussion is presented in sections on the different kinds of feedstocks.

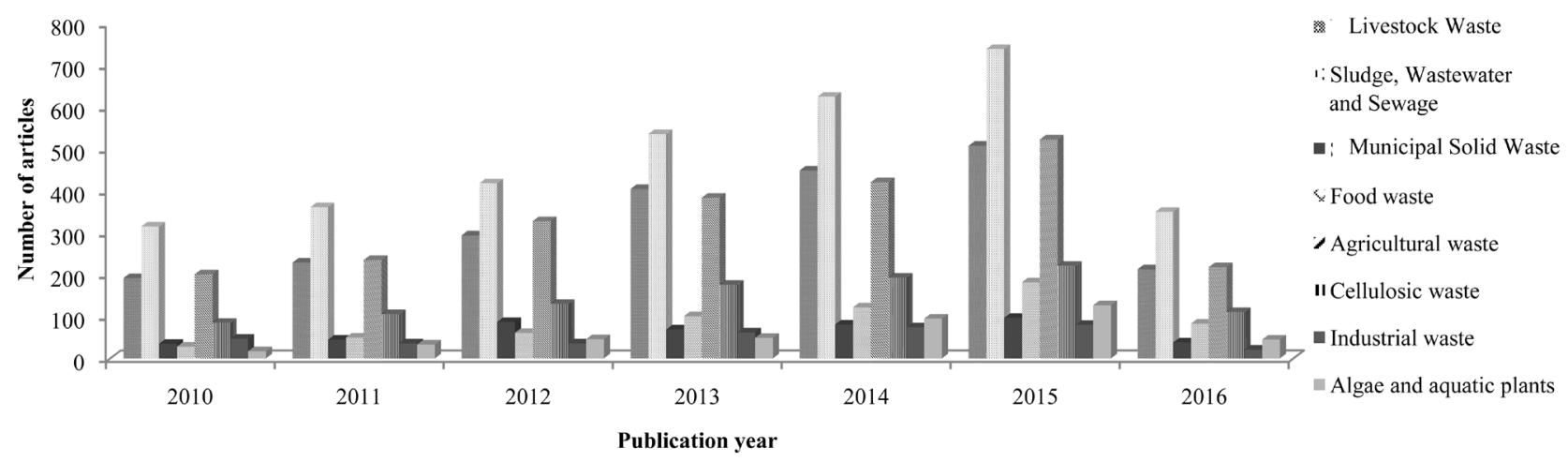

Figure 2. Number of publications per year per type of potential AD feedstock.

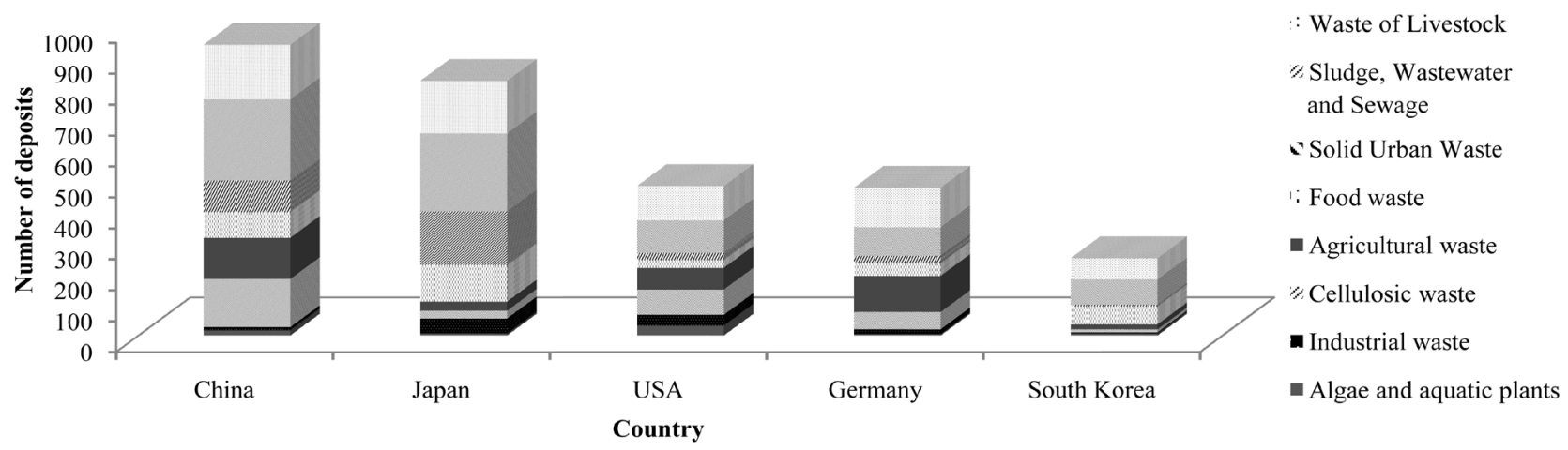

Figure 3. Number of patent applications per priority country for each type of AD feedstock.

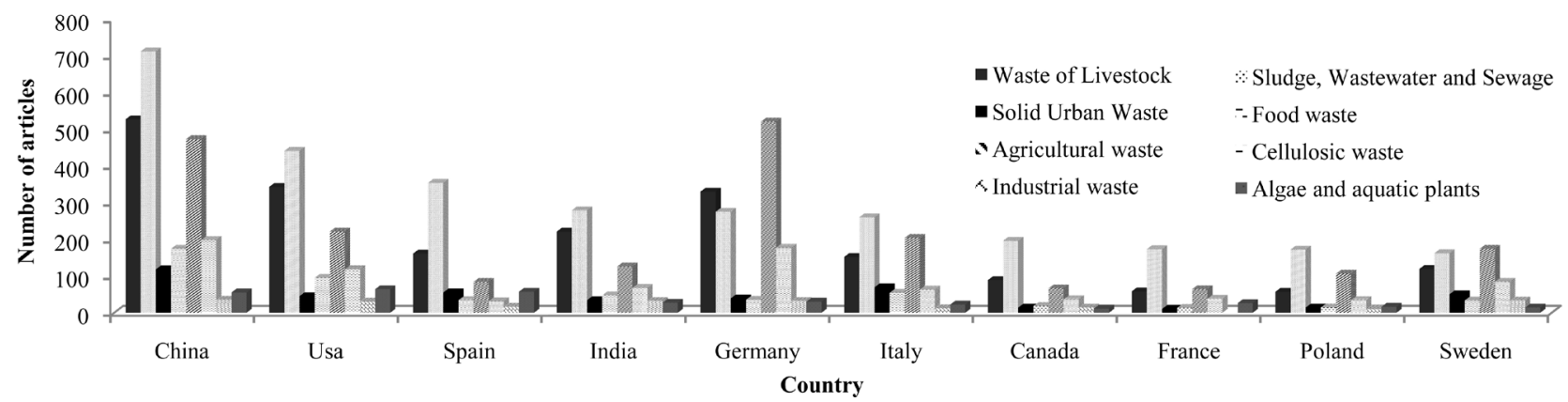

Figure 4. Number of publications per country for each type of AD feedstock. 


\subsection{Main Waste Materials Used as Feedstock for Biogas Production}

In view of the breadth and diversity of the findings of this study, the decision was taken to discuss only the groups of waste materials that accounted for $12 \%$ or more of the patents retrieved. As such, the following groups will be discussed: wastewater, sludge, and sewage (25\%), animal waste (23\%), and agricultural waste (14\%).

\subsubsection{Wastewater, Sludge, and Sewage}

Wastewater, sludge, and sewage was the group that accounted for the highest number of patent applications (970) and academic publications 4271. Anaerobic digestion is already widely used in wastewater treatment because of its high organic load. It started being used more widely for this kind of treatment in the 1980s, when the first UASB reactors were developed [12]. The finding of this research that domestic wastewater is an important feedstock for biogas generation has also been reported elsewhere [13] [14]. Wastewater and even MSW treatment are associated with the need for the private sector to remain profitable. Generally, companies make use of waste materials because they need to comply with environmental effluent disposal and treatment legislation, and anaerobic digestion is a way for them to do so while also generating energy via biogas [15]. The temporal evolution of the academic publications (Figure 2) shows that the number of studies of this kind of feedstock has grown consistently over the study period at an average of $2.5 \%$ a year. There is clearly still interest in researching more about the generation of biogas from sewage, sludge, and wastewater.

When it comes to the countries with the most interest in developing this technology (countries where the most priority patent applications have been filed), the top five countries account for $82 \%$ of all the patents retrieved for this category. China and Japan, with 262 and 253 patent applications respectively, are the leading countries. As for the academic publications, indicators of research activity, the top countries are China (712 publications), the USA (414), Spain (354), India (279), Germany (275), and Italy (260) (Figure 3).

\subsubsection{Livestock Waste}

The second biggest group, with 3046 publications and 863 patent applications, has to do with the use of animal waste. The motivation for developing and protecting intellectual property for this kind of waste is certainly associated with the size and importance of livestock farming. Only in 2015, the 28 member countries of the European Union slaughtered 7590.34 thousand tons of beef, with France alone holding some 19.3 million heads of cattle. As for pork production, the leaders in this economic bloc are Germany and Spain, with 28.3 million and 26.6 million pigs, respectively [16]. Animal waste, manure, and feces could offer a good opportunity for sustainable rural development. Large and small farms could use anaerobic digestion to produce biogas, while also reducing environmental pollution and contamination with pathogens and vectors caused by the incorrect disposal of manure, for instance [17]. Another positive point is that 
using farm waste is good for reducing greenhouse gas emissions. The large volume of livestock farming in conjunction with the need to treat waste from this activity means that interest in $\mathrm{AD}$ has grown, especially in recent decades (Figure 3).

For a more detailed analysis, animal waste was further sub-categorized into the animals that produce the waste. Often, the same patent document cited the use of waste from more than one animal or else a combination of different types of animal waste. Fifty-one percent of the patent applications involving animal waste were for waste from cattle, $22 \%$ were for waste from pig breeding, $13 \%$ for poultry, $11 \%$ for other animals (e.g. elephant, horse, rabbit, llama, buffalo), and $3 \%$ did not mention the animal, just stating that the claim was for livestock waste.

The number of publications has grown year on year, with 2015 seeing the highest number: 508 in all. One of the factors behind the growing interest in the use of $\mathrm{AD}$ for treating livestock waste is its capacity to help integrate livestock with other farming activities, converting manure, which is normally attributed little or no commercial value, into two products of interest: renewable energy (biogas) and organic fertilizer [18].

\subsubsection{Agricultural Waste}

The third biggest group was agricultural waste, with 2879 publications and 540 patent applications. The importance of this kind of waste is linked to the ease with which the agricultural sector can undertake the co-digestion of this material (agricultural waste + livestock waste). Another driver behind the production of renewable energy from this source is the fact that aside from biogas, anaerobic digestion also generates biofertilizer, which can be fed back into the agricultural production chain, contributing to the recycling of nutrients while also reducing greenhouse gas emissions and unpleasant odors [19].

The importance of this group of waste is justified by the size of the agricultural sector in developing countries. Even so, much of the potential of this kind of waste is best harnessed in conjunction with other feedstocks in co-digestion set-ups, since crop waste is not easily degraded by microbes. However, the combined treatment of crop and livestock waste could potentially account for up to $80 \%$ of all biogas generated [20].

The co-digestion of pig manure with three crop waste products-corn stalks, oat straw, and wheat straw-has been investigated as a way of boosting biogas yields. It was found that for all types of agricultural waste, there was a considerable increase in yields when they were combined with pork waste as compared with when they were treated by $\mathrm{AD}$ alone under the same conditions [21].

Although the composition of crop waste can vary greatly, its water content tends to be low and its volatile solids content tends to be high. This means that the type of AD unit most commonly used to process it is the continuously stirred tank reactor. Around $90 \%$ of the biogas plants installed in Germany use this technology [22]. 
In this research, it was found that $64 \%$ of the patent applications that mentioned the possibility of using agricultural waste in their invention also cited waste from one or more of the other seven categories in this paper. This would indicate that technology is being developed in line with the scientific literature, which stresses that the best methane yields are obtained when agricultural waste is combined with other kinds of waste.

\subsubsection{Other Groups}

Cellulosic waste accounted for $11 \%$ of the patent documents (414) and 1264 scientific publications. The research and patenting of this kind of waste is still growing, especially given the potential need to use multiple types of pre-treatments to separate out the fibers before biodegradation.

The number of patent documents for municipal solid waste (MSW) is similar (391\%, or $11 \%)$, but there are fewer academic publications. The use of AD for treating MSW is one of the biggest breakthroughs of the last decade [23]. According to the Food and Agriculture Organization of the United Nations, it is estimated that much of the organic content of MSW is associated with food waste: a third of all the food produced in the world is wasted-the equivalent of 1.3 billion tons a year [24]. Food waste is favorable for energy recovery and reducing GHG emissions when treated by anaerobic digestion, especially because of its high levels of volatile solids and water content, which speeds up the AD process [25]. Yet even despite the good degradability and low cost of obtaining food waste, it is still not widely used [26].

Fewer patents and publications were found for industrial waste: just $4 \%$ of the patents (153) and 3\% of the publications. However, there is still an upward trend in the use of this kind of waste. The main industries with biogas generation potential are pulp and paper, sugar and ethanol, abattoirs, dairy, breweries, food, and drink, all of which need to reduce the organic load of their effluents to comply with environmental legislation [27]. Four hundred and twenty-one publications addressing this kind of waste for $\mathrm{AD}$ were retrieved, demonstrating that research in the production of gas from industrial waste is still incipient.

Finally, algae and aquatic plants accounted for $2 \%$ of the patents (91), constituting an area of potential use that should not be overlooked. There are reports that macroalgae can reach 2 - 20 times the biofuel production potential of conventional terrestrial energy crops. Furthermore, microalgae are capable of doubling their biomass in 24 hours [28]. The authors of this study also indicate as a benefit the fact that given the negligible or minimal quantity of lignin present in aquatic plants, less pretreatment is needed. There were 438 publications retrieved concerning this group of potential raw materials, with most coming in the last decade (see Figure 2).

The scientific research in this field is wide-ranging and exploratory in nature. Meanwhile, the commercial reality is that the adoption of biogas production technologies is generally driven by economic forces or else by government legislation [15]. However, the yield of a biogas plant does not only depend on the type of feedstock, but also on its design, the fermentation temperature, and the 
hydraulic retention time [29]. This is why analyzing patenting in the area is so important for understanding the progress being made. Biogas generation could also be combined with the treatment of biodegradable municipal waste, since there is an EU directive that requires municipal solid waste disposal to be cut by $50 \%$ by 2020 [30].

While Germany is the most advanced European country when it comes to the number of AD units-8928 in 2015 [29]-the priority patent applications in this country tend to be more general and mention the use of organic waste or biomass without specifying what kind (Figure 3).

Two hundred and seventy-five patent applications filed in the United States that mention the use of some kind of waste were retrieved. The patenting in this country has remained fairly stable over the years, suggesting that while biogas production is seen as a mature technology, there is still room for technological innovation. The other countries with the most priority patents for $\mathrm{AD}$ and biogas production involving some specific waste as a feedstock between 2000 and 2016 are: South Korea (149 patent applications), Russia (82), France (58), Poland (32), and Brazil (31) (Figure 3).

Five hundred and four patent applications filed in Japan involving claims for biogas production from waste were retrieved. Brazil is in ninth position (not on the chart in Figure 3) in terms of patenting in the area, with the most significant activity between 2007 and 2010. Another country with growing patenting activity is India, which received its first priority patent application in 2005, and has been rising since, peaking in 2011. There are also many strong European countries, which is probably because of the stricter legislation in the continent, where the target is to reduce GHG emissions by $20 \%$ by 2020 .

\section{Conclusions}

There is no consensus in the literature about which raw materials are best suited for biogas production. A great deal of research is underway and the choice depends on multiple factors. These are generally associated with the geographical location and climate of the place where the biogas will be generated, the local resources, and the investments available. Government stimulus measures, such as policies designed to boost the complete use of biomass, are another driver of academic research. Finally, many of the publications investigated the combined treatment of agricultural and livestock waste. However, when the market reality was assessed, it was found that crop waste receives little attention outside universities, while raw materials from industrial plants and municipal solid waste are the types of waste that attract most commercial interest.

The choice of feedstock is therefore far from straightforward. Practical issues and operational details must be taken into account, as well as the seasonality of some waste materials and logistical considerations.

\section{References}

[1] Pastorek, Z., Kára, J. and Jevič, P. (2004) Biomass: Renewable Energy Source. FCC 
Public, Prague, 286.

[2] Mao, C.L., et al. (2015) Review on Research Achievements of Biogas from Anaerobic Digestion. Renewable and Sustainable Energy Reviews, 45, 540-555.

https://doi.org/10.1016/j.rser.2015.02.032

[3] Yang, L.L., et al. (2015) Enhancing Biogas Generation Performance from Food Wastes by High-Solids Thermophilic Anaerobic Digestion: Effect of pH Adjustment. International Biodeterioration \& Biodegradation, 105, 153-159. https://doi.org/10.1016/j.ibiod.2015.09.005

[4] BGS Equipamentos (2014) Histórico do Biogás. http://bgsequipamentos.com.br/blog/hello-world/

[5] Sosnowski, P., Wieczorek, A. and Ledakowicz, S. (2003) Anaerobic Co-Digestion of Sewage Sludge and Organic Fraction of Municipal Solid Wastes. Advances in Environmental Research, 7, 609-616. https://doi.org/10.1016/S1093-0191(02)00049-7

[6] Mulinda, C., Hu, Q.C. and Pan, K. (2013) Dissemination and Problems of African Biogas Technology. EPE, 5, 506-512. https://doi.org/10.4236/epe.2013.58055

[7] Global Intelligence Alliance (2010) How to Profit from Biogas Market Developments. GIA Industries White Paper, United States.

[8] Ajeej, A., et al. (2015) An Overview of Bio Augmentation of Methane by Anaerobic Co-Digestion of Municipal Sludge Along with Microalgae and Waste Paper. Renewable and Sustainable Energy Reviews, 50, 270-276.

https://doi.org/10.1016/j.rser.2015.04.121

[9] Alves, J.M.S. (2003) Análise de Patentesnaindústria Avícola Internacional. 123 f. Dissertação (Mestrado), Curso de Agronegócios, Centro de Estudos e PesquisaemAgronegócios, Universidade Federal do Rio Grande do Sul, Porto Alegre. http://www.lume.ufrgs.br/bitstream/handle/10183/4851/000505489.pdf

[10] Porter, A.L., Roper, A.T., Mason, T.W., Rossini, F.A. and Banks, J. (1991) Forecasting and Management of Technology. Wiley Series in Engineering and Technology Management, Estados Unidos.

[11] Smyth, B.M., Murphy, J.D. and O’brien, C.M. (2009) What Is the Energy Balance of Grass Biomethane in Ireland and Other Temperate Northern European Climates? Renewable and Sustainable Energy Reviews, 13, 2349-2360.

[12] Chernicharo, C.A.L., et al. (2015) Anaerobic Sewage Treatment: State of the Art, Constraints and Challenges. Reviews in Environmental Science and Bio/ Techno$\log$, 14, 649-679.

[13] Bougrier, C., Delgenès, J.-P. and Carrère, H. (2006) Combination of Thermal Treatments and Anaerobic Digestion to Reduce Sewage Sludge Quantity and Improve Biogas Yield. Process Safety and Environmental Protection, 84, 280-284.

[14] Luostarinen, S., Luste, S. and Sillanpää, M. (2009) Increased Biogas Production at Wastewater Treatment Plants through Co-Digestion of Sewage Sludge with Grease Trap Sludge from a Meat Processing Plant. Bioresource Technology, 100, 79-85.

[15] Suvi, H., Kaisa, M. and Pekka, L. (2014) Combining Biogas LCA Reviews with Stakeholder Interviews to Analyse Life Cycle Impacts at a Practical Level. Journal of Cleaner Production, 80, 5-16.

https://doi.org/10.1016/j.jclepro.2014.05.081

[16] European Community Eurostat (2015) Slaughtering in Slaughterhouses. https://data.europa.eu/euodp/en/data/dataset/bWjOnCTyzneXJ36uHJv5vw

[17] Al-Rousan, A. and Zyadin, A. (2014) A Technical Experiment on Biogas Production from Small-Scale Dairy Farm. Journal of Sustainable Bioenergy Systems, 4, 10-18. https://doi.org/10.4236/jsbs.2014.41002 
[18] Angelidaki, I. and Ahring, B.K. (1994) Anaerobic Thermophilic Digestion of Manure at Different Ammonia Loads: Effect of Temperature. Water Research, 28, 727 731.

[19] Salman, Z. (2015) Biogas from Agricultural Wastes. http://www.bioenergyconsult.com/anaerobic-digestion-crop-residues

[20] Weiland, P. (2009) Biogas Production: Current State and Perspectives. Applied Microbiology and Biotechnology, 85, 849-860.

[21] Wu, X., et al. (2010) Biogas and CH4 Productivity by Co-Digesting Swine Manure with Three Crop Residues as an External Carbon Source. Bioresource Technology, 101, 4042-4047.

[22] Gerhardt, M. (2007) The Use of Hydrolytic Enzymes in Agricultural Biogas Production. Progress in Biogas, Stuttgart, 247-254.

[23] De Baere, L. (2006) Will Anaerobic Digestion of Solid Waste Survive in the Future? Water Science \& Technology, 53, 187-194. https://doi.org/10.2166/wst.2006.249

[24] Bojanic, A. (2014) Enquanto milhões passam fome, 1, 3 bi de toneladas de comida é desperdiçado.

http://noticias.uol.com.br/opiniao/coluna/2014/05/06/enquanto-milhoes-passam-fo me-13-bi-de-toneladas-de-comida-e-desperdicado.htm

[25] Kim, D.H., Kim, S.H., Kim, H.W., Kim, M.S. and Shin, H.S. (2011) Sewage Sludge Addition to Food Waste Synergistically Enhances Hydrogen Fermentation Performance. Bioresource Technology, 102, 8501-8506.

https://doi.org/10.1016/j.biortech.2011.04.089

[26] Zhang, J., et al. (2014) Anaerobic Digestion of Food Waste Stabilized by Lime Mud from Papermaking Process. Bioresource Technology, 170, 270-277.

[27] Havukainen, J., et al. (2014) Evaluation of Methods for Estimating Energy Performance of Biogas Production. Renewable Energy, 66, 232-240.

[28] Montingelli, M.E., Tedesco, S. and Olabi, A.G. (2015) Biogas Production from Algal Biomass: A Review. Renewable and Sustainable Energy Reviews, 43, 961-972.

[29] Hofmann, F. (2016) Biogas in Germany-Development, Technology and Benefits. Energy Solutions, Warsaw.

http://ahk.pl/fileadmin/ahk polen/Erneuerbare Energien/2016 03 Frank Hofman n.pdf

[30] Holm-Nielsen, J.B., Seadi, T.A. and Oleskowicz-Popiel, P. (2009) The Future of Anaerobic Digestion and Biogas Utilization. Bioresource Technology, 100, 54785484 . 
Submit or recommend next manuscript to SCIRP and we will provide best service for you:

Accepting pre-submission inquiries through Email, Facebook, LinkedIn, Twitter, etc. A wide selection of journals (inclusive of 9 subjects, more than 200 journals)

Providing 24-hour high-quality service

User-friendly online submission system

Fair and swift peer-review system

Efficient typesetting and proofreading procedure

Display of the result of downloads and visits, as well as the number of cited articles Maximum dissemination of your research work

Submit your manuscript at: http://papersubmission.scirp.org/

Or contact jep@scirp.org 